\title{
Financial Performance Impacts of Corporate Entrepreneurship
}

\author{
Bertha Silvia Sutejo \\ Dosen Jurusan Manajemen \\ Fakultas Bisnis dan Ekonomika Universitas Surabaya \\ bertha@staff.ubaya.ac.id
}

\begin{abstract}
Abstact
This paper examine about the effect of four sub-dimensions of corporate entrepreneurship (CE) on firms' financial performance in Indonesia. The four sub-dimensions are innovativeness, risk-taking, pro-activeness, and competitive aggressiveness. This study will use primary data by the way spread some questioner in the company. To test the financial performance effects of $C E$, the scale for the dimensions of $C E$ and financial performance have been adopted from the existing literature. A series of reliability and validity tests are conducted for the measurement of the scales. Validity and reliability test and multiple regression analysis have been conducted to test the hypotheses. The results of this research will provide guidelines to help investors, managers, and also academicians to comprehend the importance of $C E$ well on the way to create financially successful firm performance and sustain it in markets.
\end{abstract}

Keywords: Financial Performance, Corporate Entrepreneurship

\begin{abstract}
Abstak
Penelitian ini menjelaskan tentang pengaruh 4 dimensi dalam Corporate Entrepreneurship (CE) terhadap kinerja keuangan perusahaan di Indonesia. Keempat dimensi adalah innovativeness, risk-taking, pro-activeness, dan competitive aggressiveness. Penelitian ini menggunakan data primer dengan cara menyebar kuesioner ke perusahaan. Untuk menguji kinerja keuangan dipengaruhi oleh CE, skala untuk dimensi CE dan kinerja keuangan diadopsi dari literature yang sudah ada. Uji reliabilitas dan validitas dilakukan untuk mengukur skala. Uji reliabilitas, validitas, dan analisis regresi berganda dilakukan untuk menguji hipotesis. Hasil penelitian ini akan memberikan petunjuk yang membantu investor, manajer, dan juga akademisi untuk memahami pentingnya CE sebagai langkah menciptakan kesuksesan financial dan bertahan dalam pasar.
\end{abstract}

Kata Kunci: Kinerja Keuangan, Corporate Entrepreneurship 